\title{
Accounting Analysis of Banking Companies Listed in IBEX35 in Period of Financial Crisis
}

\author{
Miguel Angel Pérez Benedito ${ }^{1}$ \\ ${ }^{1}$ Faculty of Economics. Valencia University, Valencia, Spain. \\ Correspondence: Miguel Angel Pérez Benedito, Avda dels Tarongers s/n, 46022, Valencia, Spain
}

Received: May 5, 2015

Accepted: May 20, 2015

Available online: May 29, 2015

doi:10.11114/aef.v2i3.847

URL: http://dx.doi.org/10.11114/aef.v2i3.847

\begin{abstract}
This manuscript presents a new methodology to measure the behavior of banking companies. It is based on equilibrium a criterion which is always on a balance sheet, and the main issue is the economic and financial significance of this equilibrium. The accounting analysis based on the Edgeworth's box analyzes an observation by means of two indicators, which measures the economic and financial significance of each annual observation at same time. This characteristic allows the measure of the decision making on two different criteria, according to evolution of macroeconomic variables. Moreover, undetermined values have financial and economic significances because the behavior of companies has a limit on this methodology. This manuscript presents the accounting methodology of the Edgeworth's box in the first chapter. Then, the behavior of banking companies is analyzed as qualitative and quantitative criteria to carry out the result of research in the second chapter. Conclusions are referred to the analytic capacity of this methodology and research results.
\end{abstract}

Keywords: new methodology, accounting analysis, manager behavior, undetermined values.

\section{Introduction}

The financial crisis has been solved by applying criteria of monetary policies and several strategies have been applied in order to know the situation and evolution of the financial market. So, studies on interest rates (Aghion, Bacchetta, \& Banerjee, 2000. Chistiano, Gust \& Roldos, 2004), additional information on financial agents (Adiran \& Shin, 2009), financial variables that measure the financial activity of domestic economies (Schularick \& Taylor, 2009) and responsibility of government (Taylor, 2009) indicate that there is not a singular solution or a categorical answer for overcoming financial perturbations on recent past.

The position of the financial market has been offering trust to investors through additional information that public and private agents must report on their activity. The new framework of International Public Accounting Standards (IFAC, 2014), IFRS Practice Statement on Management Commentary (IASB, 2010) and General Principles Regarding Disclosure of Management's Discussion and Analysis of Financial Condition and Results of Operations (IOSCO, 2003) aim to offer additional information of management activity of all listed companies. This additional information reports on the prospective position of companies, qualitative information and additional indicators of their activity. These changes in the reports of companies want to improve the perception of risk of management of companies for investors and general public. In other words, new standards aim to avoid transferring moral hazard of financial institutions to customers (Bonollo, Crimaldi, Flori, Pammolli \& Ricaboni, 2015. Allen, Carletti, Goldstein. \& Leonello, 2015).

The methodology on the Edgeworth's box shows the equilibrium of any given company. This methodology is based on the criterion that a balance sheet presents an equilibrium, and its analysis allows the knowledge of the economic and financial situation of a company on a year on an observation of the Edgeworth's box, but all this at the same time (Pérez, 2014, 2015). According to the accounting method of double entry, an economic transaction is related to a financial transaction and it allows the change of the value of a good into a financial good. A balance sheet presents the result of these transformations, and it will have assets and liabilities with economic and financial significance respectively. By transferring this equilibrium to an Edgeworth's box it is possible to explain the behavior of companies according to their economic and financial significance. Moreover, observations of the Edgeworth's box will have a limit and their undetermined values have always economic and financial significance, this is the same as reaching a limit on a balance sheet. 
The accounting methodology of the Edgeworth's box explains the situation of companies by four accounting variables at the same time, and analysts can measure risk positions according to the location of companies in the Edgeworth's box. It synthesizes the economic and financial positions of companies for public on a single observation, and by two different indicators, which measure economic and financial positions of companies. The relation between company and economic environment where companies make their activity can be better explained, because the subjective character of indicators is smoothed. In summary, this methodology is in accordance with tendency of international institutions to explain the behavior of economic agents by several kinds of information, but it offers synthesized information and their undetermined values will have an economic and financial significance.

\section{Method: The Accounting Methodology of the Edgeworth's Box (AMEB).}

According to AMEB, a company is an economic agent with two kinds of transactions. These are economic and financial, and also positive and negative. A negative economic transaction is an acquisition of production factors from an economic market and, at the same time, a negative financial transaction arises as counterparty. Therefore, when a company sells or alienates their products on an economic market, a positive economic transaction is made, and at same time, a positive financial transaction arises as counterparty. These relations between economic and financial transactions are entries in an accounting system according to the method of double entry and the criterion of accrual accounting to measure the activity of a company on two kinds of markets. Considering financial transactions as counterparties of economic transactions, the activity of companies can be explained as relations of companies with economic or financial markets and the results of two kinds of relations are related.

Expression 1 represents the result of the company's transactions.

$$
(\mathrm{ET}+)-(\mathrm{ET}-)=(\mathrm{FT}+)-(\mathrm{FT}-)
$$

The result of singular differences of expression 1 is on expression 2 .

$$
\mathrm{OR}-\Delta \mathrm{RA}=\mathrm{ML}-\Delta \mathrm{FP}
$$

The difference between economic transactions are the operative result $(\mathrm{OR})$ and variations of assets $(\triangle \mathrm{RA})$. The OR does not include effects of accounting politics of companies, and $\triangle \mathrm{RA}$ are values of not sold economic assets on the economic market. The difference of financial transactions is the monetary liability (ML) and the value of variations of financial positions of companies $(\triangle \mathrm{FP})$. The monetary liability is the monetary savings and financial products that banking clients deposit on a Bank and $\Delta \mathrm{FP}$ are financial instruments, which have not been settled in the financial market. Therefore, $\Delta \mathrm{FP}$ is the difference between credits and liabilities of banking companies according to their activities on the financial market and they can come from economic and financial activity, as credits of customers and suppliers or financial assets and debts. Table 1 shows the variables of AMEB obtained from ORBIS database of BANKIA.

Table 1. Variations of accounting variables of BANKIA.

\begin{tabular}{llll}
\hline Y E A R S >>>>>>>>>>>>> & $\mathbf{2 0 1 3}$ & $\mathbf{2 0 1 2}$ & $\mathbf{2 0 1 1}$ \\
\hline VARIATION OF FINANCIAL POSITION $(\Delta \mathbf{F P})$ & $\mathbf{1 5 8 1 4 7 , 7 4}$ & $\mathbf{1 5 6 9 5 9 , 3 8}$ & $\mathbf{1 8 7 2 8 1 , 4 2}$ \\
FINANCIAL ASSETS & 310379,82 & 337857,43 & 363453,54 \\
Total Earning Assets & 310379,82 & 337857,43 & 363453,54 \\
FINANCIAL LIABILITIES & 152232,09 & 180898,05 & 176172,12 \\
Other interest bearing liabilities & 120442,45 & 175686,81 & 153386,15 \\
Other (non-interest bearing) & 13460,291 & 9415,8978 & 4959,0012 \\
Loan Loss Reserves & 0 & 839,00643 & 606,58033 \\
Other Reserves & 2352,7445 & 2946,6159 & 1055,4342 \\
Equity & 15976,597 & $-7990,2861$ & 16164,952 \\
VARIATION OF REAL ASSETS $(\Delta$ RA) & $\mathbf{3 6 4 2 5 , 2 0 2}$ & $\mathbf{3 4 6 2 2 , 9 0 2}$ & $\mathbf{2 8 3 9 9 , 1 6 4}$ \\
Fixed Assets & 1827,8591 & 2161,1771 & 3539,4635 \\
Non-Earning Assets & 34597,343 & 32461,725 & 24859,701 \\
MONETARY LIABILITY $(\mathbf{M L})$ & $\mathbf{1 9 4 5 7 2 , 9 4}$ & $\mathbf{1 9 1 5 8 2 , 2 8}$ & $\mathbf{2 1 5 6 8 0 , 5 8}$ \\
Deposits \& short term funding & 194572,94 & 191582,28 & 215680,58 \\
OPERATIVE RESULT $(\mathbf{O R})$ & $\mathbf{2 4 0 6 , 6 6 7 3}$ & $\mathbf{- 1 3 3 3 , 7 8 1 4}$ & $\mathbf{1 7 7 , 5 2 3 0 8}$ \\
Loan Loss Provisions & 1704,7055 & 23988,934 & 4029,2046 \\
Net Income & 701,96188 & $-25322,716$ & $-3851,6816$ \\
\hline
\end{tabular}

The next step to measure the behavior of BANKIA is the adjustment before the result of accounting variables according to information obtained from ORBIS database. So the OR is deduced from $\Delta \mathrm{FP}$, and values of accounting variables applied are on Table 2. 
Table 2. Accounting variables of AMEB to BANKIA

\begin{tabular}{llll}
\hline BANKIA & $31 / 12 / 2013$ & $31 / 12 / 2012$ & $31 / 12 / 2011$ \\
\hline FINANCIAL POSITION $(\triangle \mathrm{PF})$ & 1188,3561 & $-30322,036$ & $-7068,5904$ \\
REAL ASSETS $(\triangle \mathrm{AR})$ & 1802,3001 & 6223,7375 & 608,38799 \\
\cline { 2 - 4 } & 2990,6562 & $-24098,299$ & $-6460,2024$ \\
\cline { 2 - 4 } & & & \\
MONETARY LIABILITY $(\mathrm{ML})$ & 583,98882 & $-22764,517$ & $-6637,7255$ \\
OPERATIVE RESULT $(\mathrm{OR})$ & 2406,6673 & $-1333,7814$ & 177,52308 \\
\cline { 2 - 4 } & 2990,6562 & $-24098,299$ & $-6460,2024$ \\
\hline
\end{tabular}

The next step is the transformation on positive values of all values of accounting variables. So that, the highest negative value of table 2 is multiplied by minus two (-2), and later the result $(60,644.07224)$ is added to all values of accounting variables. It represents a change of origin of coordinates, and the $y$-axis is transformed to obtain all values positive. Table 3 shows the new values of accounting variables of AMEB.

Table 3. First transformation of accounting variables of AMEB.

\begin{tabular}{llll}
\hline FINANCIAL POSITION $(\triangle \mathrm{PF})$ & 61832,428 & 30322,036 & 53575,482 \\
\hline REAL ASSETS $(\triangle \mathrm{RA})$ & 62446,372 & 66867,81 & 61252,46 \\
\cline { 2 - 4 } & 124278,8 & 97189,846 & 114827,94 \\
\cline { 2 - 4 } & & & \\
MONETARY LIABILITY $(\mathrm{ML})$ & 61228,061 & 37879,555 & 54006,347 \\
OPERATIVE RESULT $(\mathrm{OR})$ & 63050,74 & 59310,291 & 60821,595 \\
\cline { 2 - 4 } & 124278,8 & 97189,846 & 114827,94 \\
\hline
\end{tabular}

The next transformation measures the financial position of a company using the same criteria in each year to represent its relative position in an Edgeworth's box.

Table 4. Relative position of BANKIA in an Edgeworth's box.

\begin{tabular}{llll}
\hline YEARS & $31 / 12 / 2013$ & $31 / 12 / 2012$ & $31 / 12 / 2011$ \\
\hline FINANCIAL POSITION $(\triangle \mathrm{FP})$ & $49,75 \%$ & $31,20 \%$ & $46,66 \%$ \\
REAL ASSETS $(\triangle \mathrm{AR})$ & $50,25 \%$ & $68,80 \%$ & $53,34 \%$ \\
\cline { 2 - 4 } & $100,00 \%$ & $100,00 \%$ & $100,00 \%$ \\
\cline { 2 - 4 } & & & \\
MONETARY LIABILITY $(\mathrm{ML})$ & $49,27 \%$ & $38,97 \%$ & $47,03 \%$ \\
OPERATIVE RESULT $(\mathrm{OR})$ & $50,73 \%$ & $61,03 \%$ & $52,97 \%$ \\
\cline { 2 - 4 } & $100,00 \%$ & $100,00 \%$ & $100,00 \%$ \\
\hline
\end{tabular}

The situation of accounting variables on table 3 in an Edgeworth's box is shown in figure 1. The variable of variation of real assets $(\triangle \mathrm{RA})$ is represented on the primary $\mathrm{y}$-axes, and monetary liability (ML) is represented on the primary $\mathrm{X}$-axes. Moreover, the variable of operative result $(\mathrm{OR})$ is represented on the secondary $\mathrm{x}$-axes, and the variable financial position on the secondary y-axes. The assets variables are represented on the y-axes, and the liability variables are represented the on $\mathrm{x}$-axis, and each kind of two variables always sums $100 \%$. 


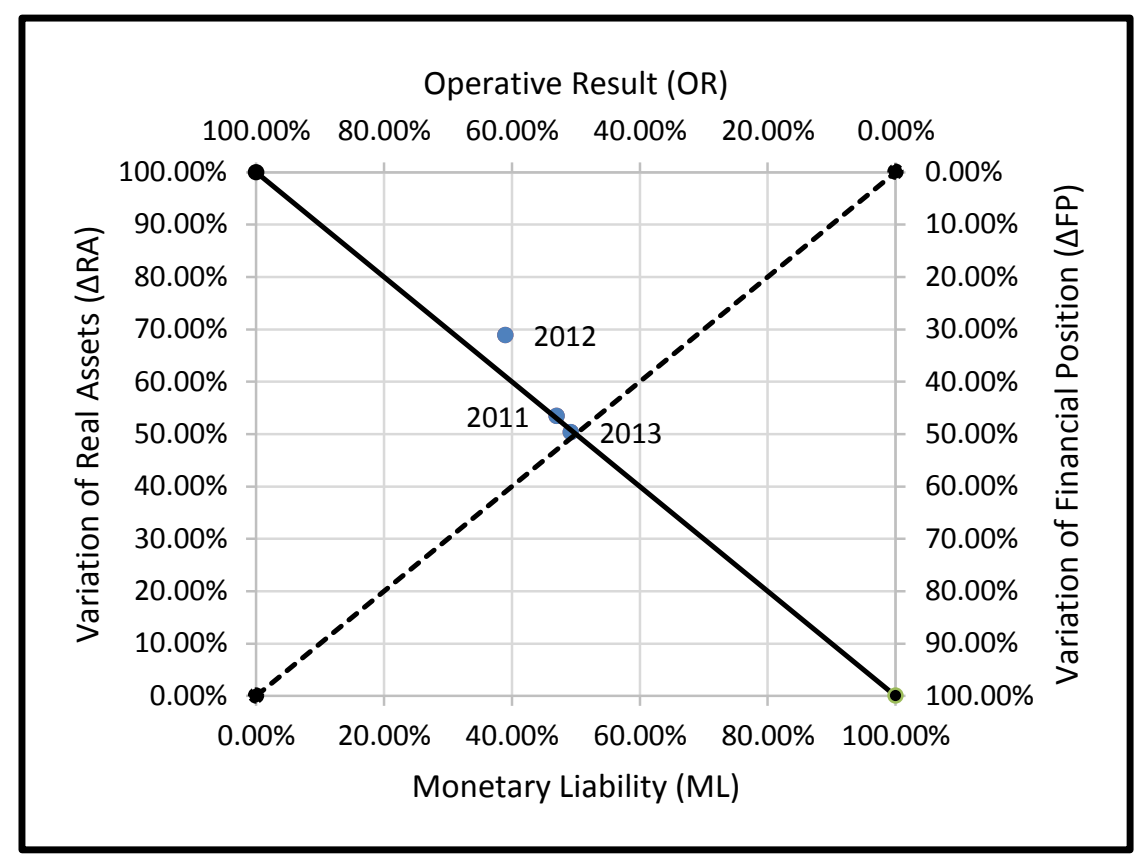

Figure 1. Edgeworth's' box of BANKIA

Two indicators are made to evaluate the positions of BANKIA in an Edgeworth's box. The indicator L is represented on continued line and the indicator $\mathrm{G}$ is represented with dashed line in Figure 1. The valuation of $\mathrm{L}$ and $\mathrm{G}$ indicators is measured according to expressions 3 and 4 detailed below.

The expression 3 is the indicator $\mathrm{L}$. This indicator is obtained by differences between relations of variables $\Delta \mathrm{FP}$ and OR with relation of $\triangle \mathrm{RA}$ and ML. The first relation $\triangle \mathrm{FP} / \mathrm{OR}$ measures how many times the OR is covered by the credit that a bank concedes to customers. The second relation $\triangle \mathrm{RA} / \mathrm{ML}$ measures the guaranties of liquid deposit with real assets of a banking company. The significance of L indicator is as follows:

a) A positive value of $\mathrm{L}$ indicator is given when markets do not have perturbations; banks will trust the financial situation of the economy and will give credit to the market.

b) A negative value of L indicator is given when banks guarantee their financial position with economic assets and do not concede credit to customers.

$$
\mathrm{L}=\Delta \mathrm{FP} / \mathrm{OR}-\Delta \mathrm{RA} / \mathrm{ML}
$$

Expression 4 is the indicator $\mathrm{G}$. This indicator is obtained by differences between economic ratio and financial ratio. The relation $\triangle \mathrm{RA} / \mathrm{OR}$ measures how many times the operative result (OR) is covered by the increasing of assets $(\triangle \mathrm{RA})$. The second relation $\triangle \mathrm{FPA} / \mathrm{ML}$ measures how many times the deposits of customers (ML) are included on credit conceded by banks to customers $(\Delta \mathrm{F})$. The significance of $\mathrm{G}$ indicator is as follows.

a) A positive value of $\mathrm{G}$ indicator is given when bank depositors have a high level of trust, and so, the banking company has a level of guarantees because its investments are on real assets.

b) A negative value of $\mathrm{G}$ indicator is given when a bank does not have the trust of customers and the economic guarantees are approached or lower than the operative result.

$$
\mathrm{G}=\Delta \mathrm{RA} / \mathrm{OR}-\Delta \mathrm{FP} / \mathrm{ML}
$$

According to these criteria of measures, activities of bank companies can be measured in The Edgeworth's box, as it is presented on Table 5. 
Table 5. Positions on The Edgeworth's box

\begin{tabular}{ccc}
\hline & G+ & G- \\
\hline L+ & ZONE A & ZONE D \\
L- & ZONE B & ZONE C \\
\hline
\end{tabular}

The different positions that a bank can take according to its behavior are on table 5. The best position is appointed as letter $\mathrm{A}$, because it is indicating that the bank grants credit to the financial market and has liquidity according to the level of monetary savings of its customers. On position $\mathrm{C}$ the bank has an opposite position to zone A. The bank does not grant credit to the market because the level of banking deposits of customer is lower than in zone $\mathrm{A}$, and the bank does not have liquidity. There are economic and financial perturbations in zone $\mathrm{C}$. The others zones are intermediate positions and represent changes of behavior, changing from best to worst positions and vice versa. Table 6 has the values of BANKIA, and the results show difficulties on its behavior.

Table 6. Results of BANKIA on The Edgeworth's box.

\begin{tabular}{llll}
\hline BANKIA & $31 / 12 / 2013$ & $31 / 12 / 2012$ & $31 / 12 / 2011$ \\
\hline IND. L & $-0,0392206$ & $-1,2540303$ & $-0,2533087$ \\
IND. G & $-0,0194562$ & 0,3269379 & 0,0150621 \\
\hline
\end{tabular}

The results of tables 5 and 6 can be compared. The financial situation improves on year 2013 because the financial positions $(\triangle \mathrm{FP})$ and monetary liability (ML) increase according to the results of Table 4 . The operative result $(\mathrm{OR})$ is higher than the variation of economic assets $(\triangle \mathrm{AR})$, and the economic guarantee decreases, because BANKIA grants credit to the market by a high position of monetary liability. This is a risk position, but its position in 2013 is better than in the other two years, because it is closer to zone A in the Edgeworth's box.

Table 7. The extreme points of The Edgeworth's box.

\begin{tabular}{lccccc}
\hline VARIABLES & $1(0,0)$ & $2(0,1)$ & $3(0,0)$ & $4(1,0)$ & CENTER \\
\hline FINANCIAL POSITION $(\Delta \mathrm{FP})$ & 1 & 0 & 0 & 1 & 0,5 \\
REAL ASSETS $(\triangle \mathrm{AR})$ & 0 & 1 & 1 & 0 & 0,5 \\
MONETARY LIABILITY $(\mathrm{ML})$ & 0 & 0 & 1 & 1 & 0,5 \\
OPERATIVE RESULT $(\mathrm{OR})$ & 1 & 1 & 0 & 0 & 0,5 \\
Indicator L $=\Delta$ FP/OR- $\Delta \mathrm{RA} / \mathrm{ML}$ & $1 / 1-0 / 0$ & $0 / 1-1 / 0$ & $0 / 0-1 / 1$ & $1 / 0-0 / 1$ & 0 \\
Indicator G $=\Delta \mathrm{RA} / \mathrm{OR}-\Delta \mathrm{FP} / \mathrm{ML}$ & $0 / 1-1 / 0$ & $1 / 1-0 / 0$ & $1 / 0-0 / 1$ & $0 / 0-1 / 1$ & 0 \\
\hline
\end{tabular}

Table 7 presents the extreme points of The Edgeworth's box. The observation $1(0,0)$ is the origin of coordinates in the primary axis and the observation $3(0,0)$ is the origin of coordinates in the secondary axis. The observation $2(0,1)$ is the limit of primary $y$-axes when $\triangle \mathrm{AR}$ takes value 1 , and the primary $\mathrm{x}$-axes takes value 0 . The observation $4(1,0)$ is referred to the secondary axes, thus $\triangle \mathrm{FP}$ takes value 1 and RO takes value 0 . The CENTER column of Table 7 is in the center of the Edgeworth's box, when $\mathrm{L}$ and $\mathrm{G}$ takes values 0 , and it explains the rotation of the value to obtain the Figure 2. Moreover, the results obtained as undetermined and infinite values have economic and financial significance. Therefore, the AMEB is a methodology with a different explanatory capacity of economic success.

\section{Results of Activity on Companies Listed in Ibex35}

The result of evaluation of banking companies listed is in Figure 2. This figure is a rotation of Edgeworth's box of Figure 1 for all banking companies, and BANKIA has a triangle on the cartesian coordinates. Table 7 shows observations of Zones of Edgeworth's box in Figure 2. 


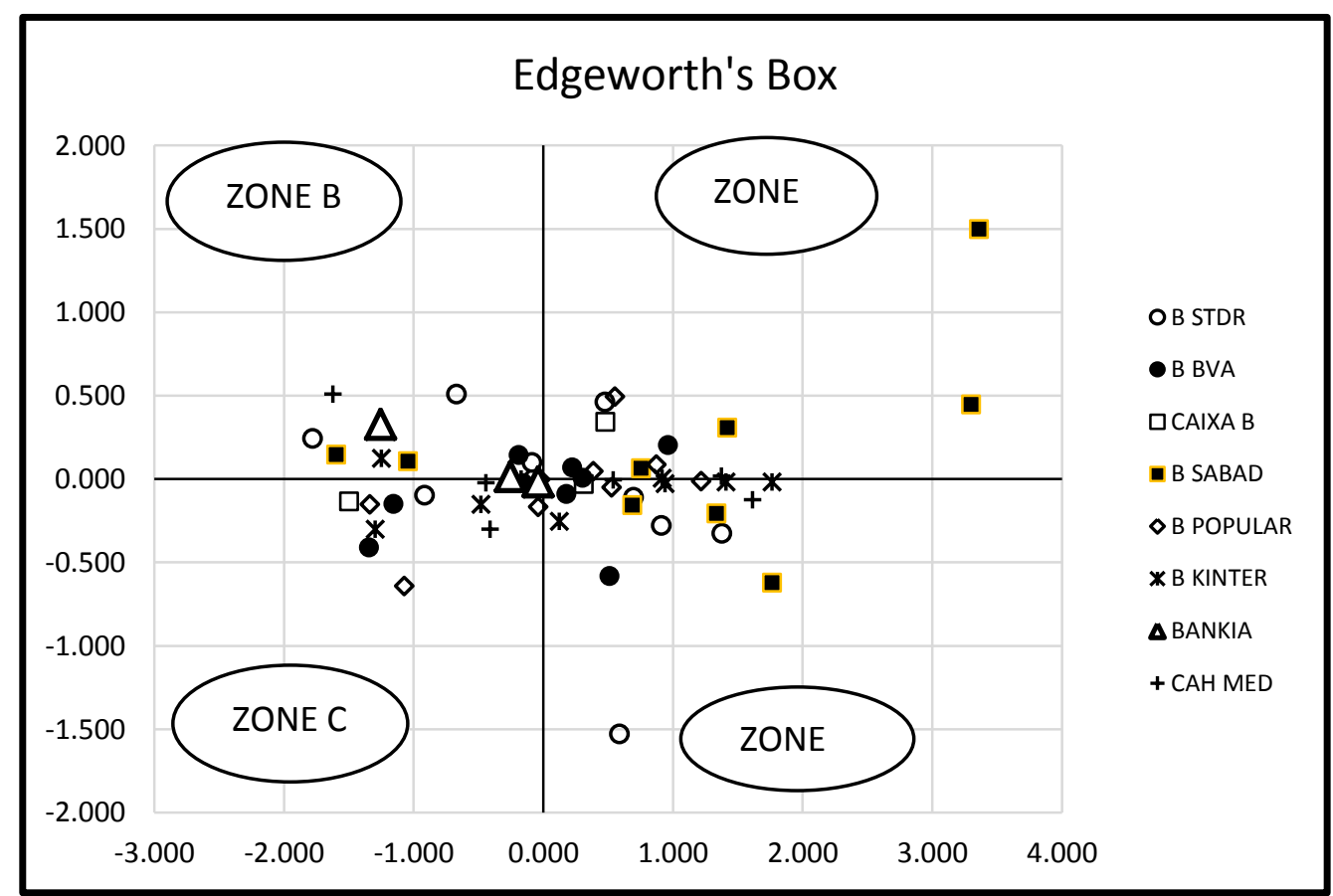

Figure 2. Zones of The Edgeworth's box.

Table 1. Observations on zones of Edgeworth's box.

\begin{tabular}{cccccccccccc}
\hline & $\mathbf{2 0 1 3}$ & $\mathbf{2 0 1 2}$ & $\mathbf{2 0 1 1}$ & $\mathbf{2 0 1 0}$ & $\mathbf{2 0 0 9}$ & $\mathbf{2 0 0 8}$ & $\mathbf{2 0 0 7}$ & $\mathbf{2 0 0 6}$ & $\mathbf{2 0 0 5}$ & $\mathbf{2 0 0 4}$ & \\
$\mathrm{A}$ & 2 & 4 & 1 & 2 & 1 & 1 & 2 & 4 & 0 & 5 & 22 \\
$\mathrm{~B}$ & 0 & 1 & 3 & 0 & 2 & 0 & 0 & 0 & 2 & 0 & 8 \\
$\mathrm{C}$ & 3 & 0 & 2 & 2 & 0 & 2 & 0 & 0 & 2 & 0 & 11 \\
$\mathrm{D}$ & 0 & 2 & 1 & 2 & 2 & 2 & 5 & 2 & 1 & 2 & 19 \\
\cline { 2 - 10 } & 5 & 7 & 7 & 6 & 5 & 5 & 7 & 6 & 5 & 7 & 60 \\
\hline
\end{tabular}

Ji2 $=0,023099606$.

The analysis of the financial crisis can be analyzed on Table 7. Comparing the same number of companies on years 2004 and 2007 there are changes of behaviors. On 2007, the risk of management is higher than on 2004 according to the number of banks located on zone D. In the period of financial crisis, from 2007 to 2010, banking companies are located on zone no A. Moreover, two companies are located on zone C in 2008 and 2010 years, indicating the high level of financial risk in this period. On 2011, banking companies leave the zones of risk, and on 2012, there are not any companies left in zone $\mathrm{C}$. Later on next year, the financial crisis arises again and banking companies change to zone $\mathrm{C}$ except for Banco Sabadell (B SABAD) and Banco Popular (B POPULAR), as it can be seen on Appendix 1. Other study researches get the same situation applying other methodologies (Suh, 2015, Caporale, Rault, Sova \& Sova, 2015) and explain the influential factors in the financial crisis during period of study (Adams, 2012). The result of Ji2 p-value of Table 7 is 0.0231 and it justifies the relation between the position of the Edgeworth's box and the annual financial situation according to opinions of other authors.

The meaning of $\mathrm{L}$ and $\mathrm{G}$ indicators obtained from banking companies listed is on Table 8, and their general behaviors are in figures 3 and 4. The general location of companies listed in the Edgeworth's box is in figure 3 and their rotations of cartesian coordinates are shown in Figure 9. It shows that banks do not have problems on years 2007, 2010, 2011 and 2012 , because they are on zone A. This situation is different to the previous qualitative analysis. 


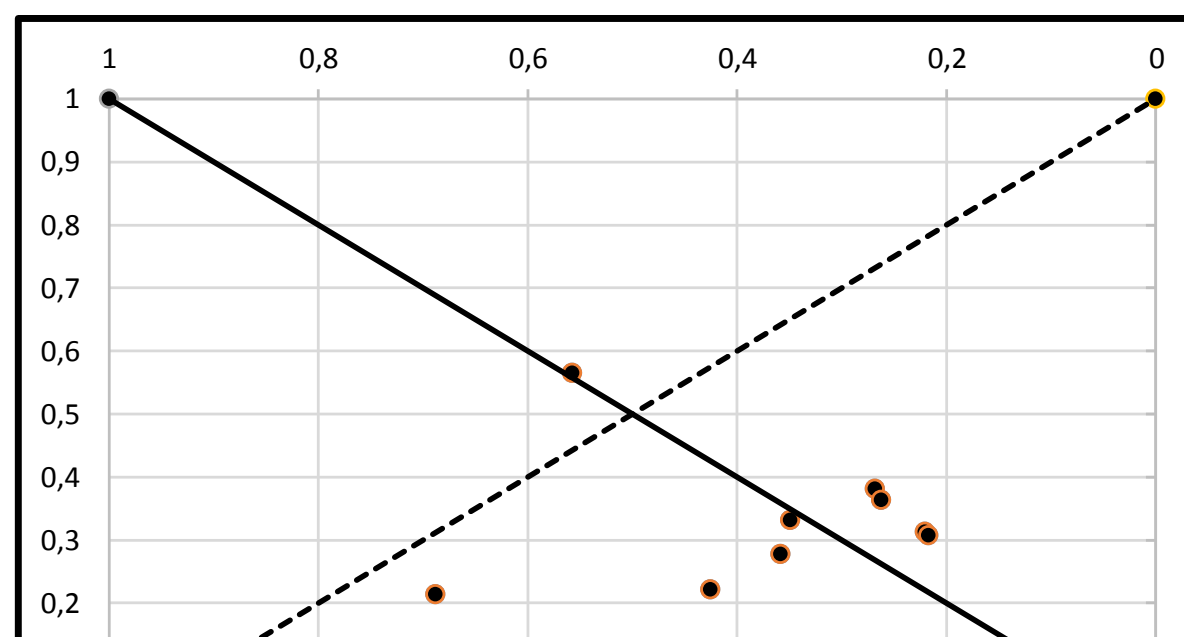

Figure 3. Mean indicators $\mathrm{L}$ and $\mathrm{G}$ of banking companies listed.

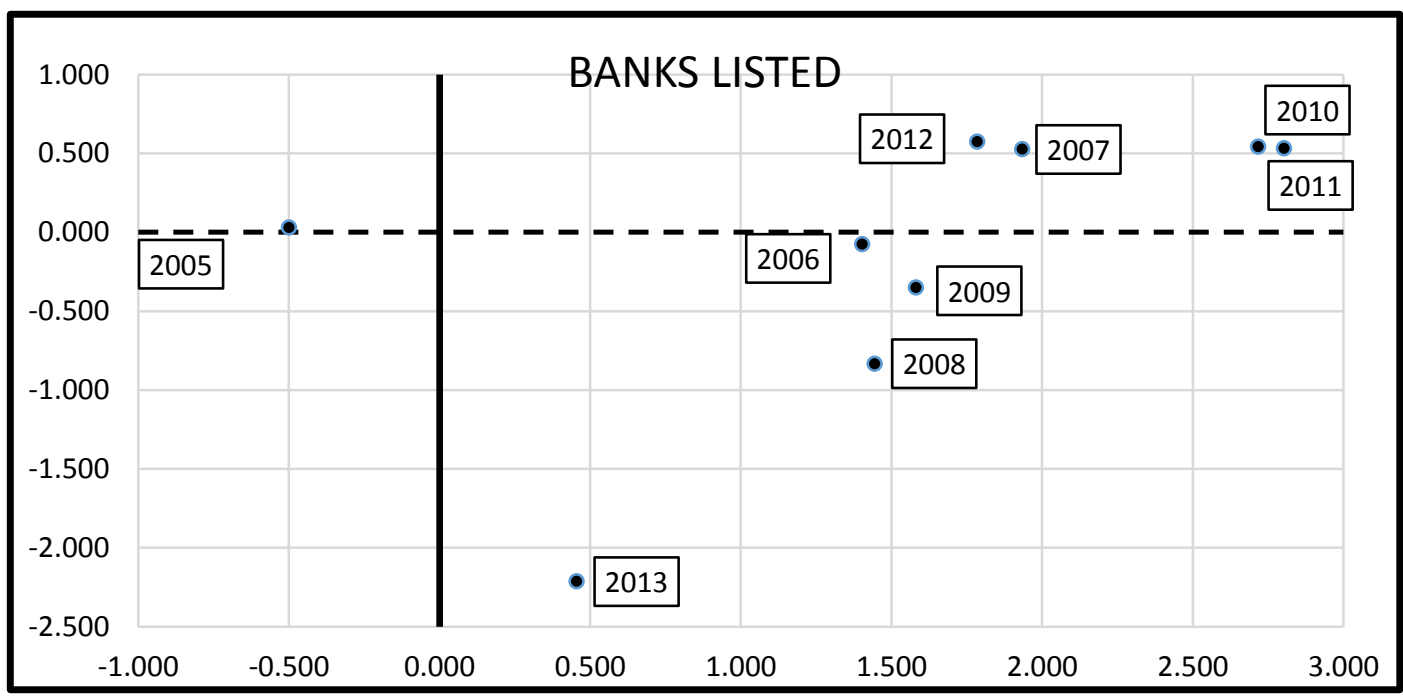

Figure 4. Rotations of L and G observations in Figure 3.

Table 8. Values of $\mathrm{L}$ and $\mathrm{G}$ indicators in figures 3 and 4.

\begin{tabular}{|c|c|c|c|c|c|c|c|c|c|c|}
\hline & 2013 & 2012 & 2011 & 2010 & 2009 & 2008 & 2007 & 2006 & 2005 & 2004 \\
\hline \multicolumn{11}{|c|}{ INDICATOR L = PF/RO - AR/PM } \\
\hline $\mathrm{PF} / \mathrm{RO}$ & 1,142 & 2,307 & 3,120 & 3,196 & 2,015 & 1,830 & 2,428 & 1,913 & 0,780 & 10,163 \\
\hline $\mathrm{AR} / \mathrm{PM}$ & 0,685 & 0,521 & 0,402 & 0,392 & 0,433 & 0,385 & 0,493 & 0,510 & 1,278 & 0,178 \\
\hline IND. L & 0,457 & 1,786 & 2,718 & 2,804 & 1,583 & 1,445 & 1,936 & 1,404 & $-0,498$ & 9,985 \\
\hline \multicolumn{11}{|c|}{ INDICATOR G = AR/RO - PF/PM } \\
\hline $\mathrm{AR} / \mathrm{RO}$ & 0,310 & 1,420 & 1,423 & 1,416 & 0,774 & 0,520 & 1,388 & 0,949 & 1,013 & 1,988 \\
\hline $\mathrm{PF} / \mathrm{PM}$ & 2,525 & 0,846 & 0,881 & 0,885 & 1,127 & 1,355 & 0,862 & 1,027 & 0,983 & 0,911 \\
\hline IND. G & $-2,214$ & 0,574 & 0,543 & 0,531 & $-0,353$ & $-0,835$ & 0,526 & $-0,078$ & 0,030 & 1,077 \\
\hline BANKS LISTED & 2013 & 2012 & 2011 & 2010 & 2009 & 2008 & 2007 & 2006 & 2005 & 2004 \\
\hline IND. L & 0,457 & 1,786 & 2,718 & 2,804 & 1,583 & 1,445 & 1,936 & 1,404 & $-0,498$ & 9,985 \\
\hline IND. G & $-2,214$ & 0,574 & 0,543 & 0,531 & $-0,353$ & $-0,835$ & 0,526 & $-0,078$ & 0,030 & 1,077 \\
\hline
\end{tabular}

Comparing results among quantitative and qualitative analysis, conclusions attained are different. The compensations among accounting variables give different results. So that, the general measures have different effects on banking companies, and justify that a quantitative and qualitative analysis must be validated to make 
decision on monetary policies, because the factor of opportunism in the theory of economic transactions of Williamson arises and the translations of moral hazard to stakeholders too (Allen et al, 2015. Blandin, Boyd \& Prescott, 2015).

To prove the validity of explanatory capacity of L and G indicators, Graphic 1 represents the evolution of the two indicators compared to the indebtedness of households and nonprofit institutions in relation with GDP, this statistical series (SI_1_3.46) is downloaded from Banco Central de España (Spanish Central Bank) and represented on secondary y-axes by a dashed line. This series has same behavior as the L indicator and the statistic of t-student proves that two variables have dependency with a high coefficient of correlations according to results of Appendix 2.

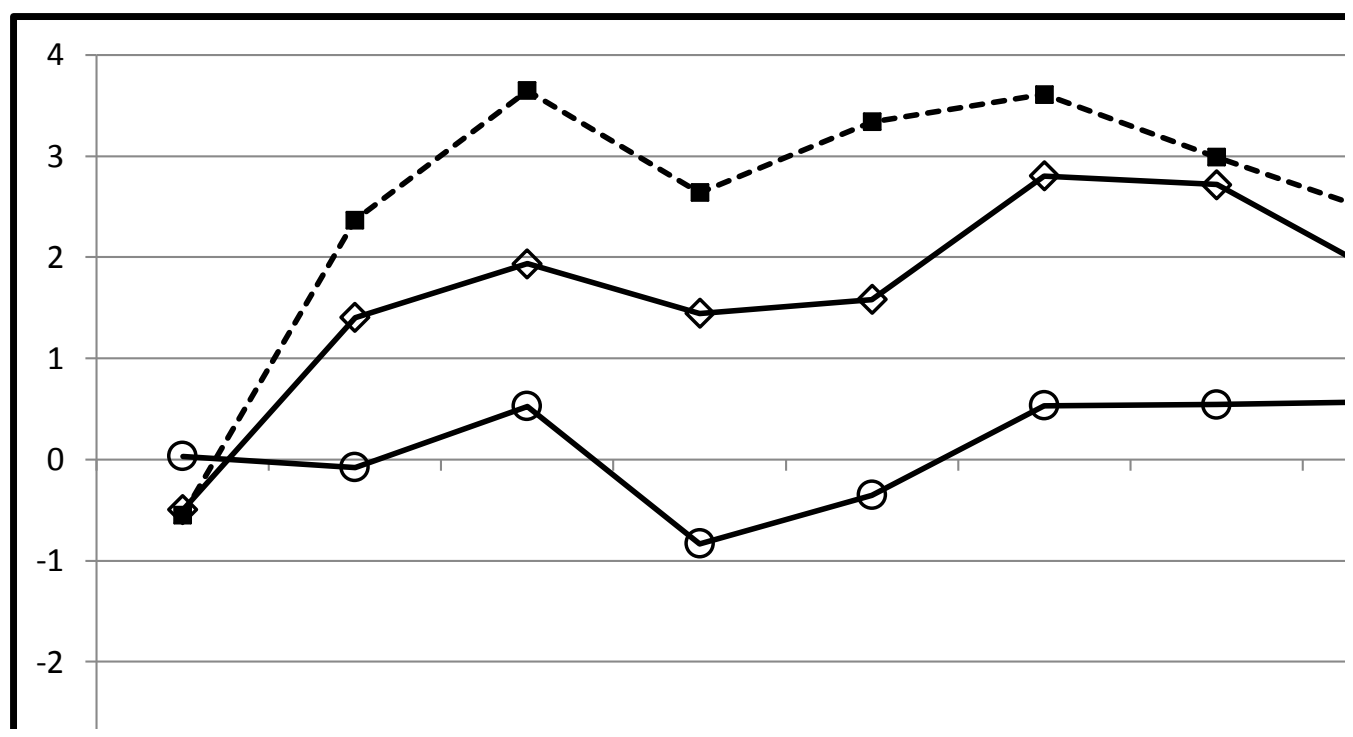

Graphic 1. Evolution of indebtedness of households (SI_1_3.46)

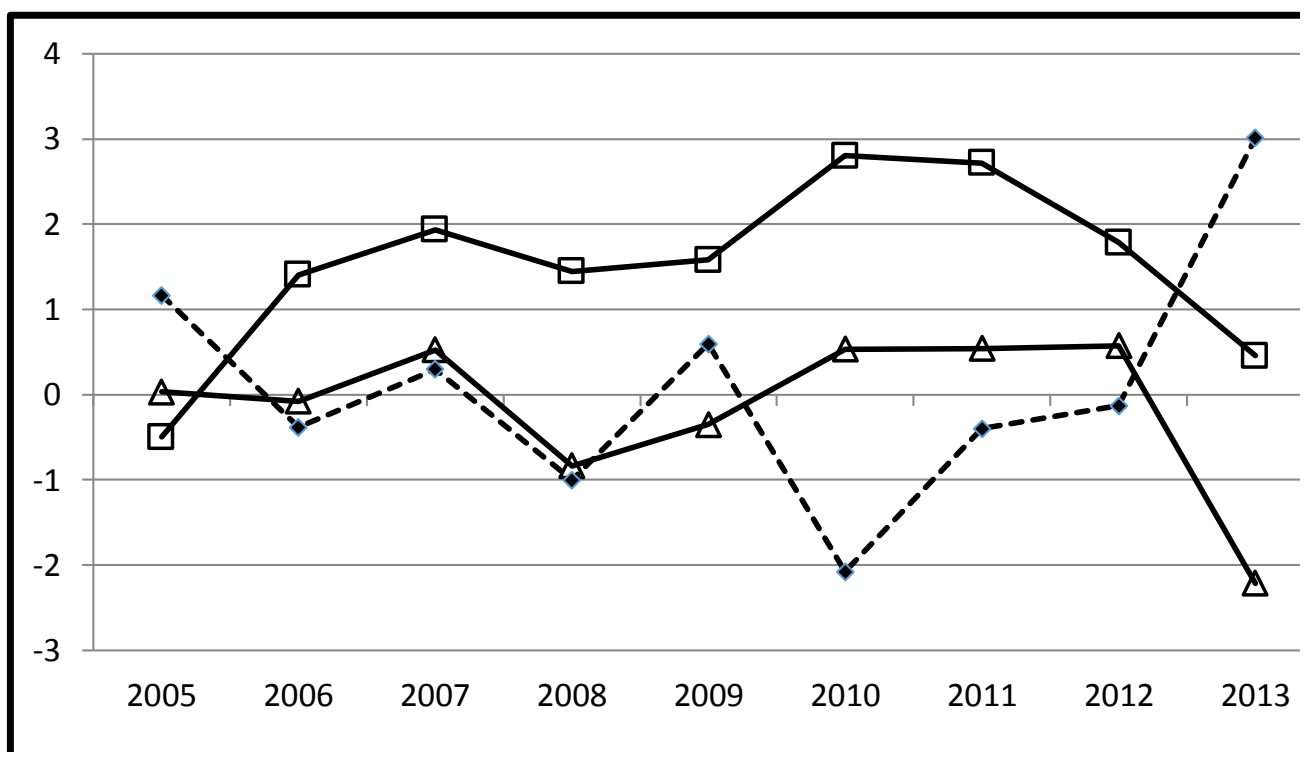

GRAPHIC 2. Evolution of inter annual variation rate of investment funds in bonds of non-financial corporations (SI_1_3.28)

The evolution of investment on bond funds made by non-banking companies has a different behavior on 2010. In graphic 2, the evolutions of $\mathrm{L}$ and $\mathrm{G}$ indicators do not have relation with inter annual variation rate of investment funds in bonds of non-financial corporations, according to results of Table 7. Table 7 presents the situation of banks in the Edgeworth's box on a qualitative criterion and it shows that in 2010, 2011 and 2013, banking companies are on C zone. In Graphic 2 the behavior of SI_1_3.28 series is different to variations of L and G 
indicators. This issue shows the same conclusions between two kinds of measures. Therefore, different tendencies between investment on bonds and $\mathrm{L}$ and $\mathrm{G}$ indicators in Graphic 2 on previous years indicate the situation of financial crisis. The situation of 2012 implies that banks need improve their activity and leave the zone C, but on 2013 three banking companies are in zone $\mathrm{C}$, this is the highest negative position on all periods, and the situation is critical. So that, $\mathrm{L}$ and $\mathrm{G}$ indicators and investment on bond funds as well as the results of Table 7 to 2013 year have the same results.

The same conclusion can be attained comparing the evolution of public debt to the gross expenses of the Government of Spain in Figure 3. The relation of these series obtained from World Bank decreases from 2008 up to 2013. In 2008, companies are on zone B of the Edgeworth's box, and taxation covers the rest of the government expenses. That is to say, the government takes liquidity from the market, and level L indicator decreases as well as level of $\mathrm{G}$ indicator, which has a negative value. On 2009, the behavior of banking companies begins to be different from the evolution of the relation between government expenses and public debt. The excess of debt over public expenses cannot be justified, and the increase of credit, measured by L indicator, and the guarantees, measured by $\mathrm{G}$ indicator, present problems inside the economic behavior of Spain (Suh, 2015). In 2011, there is a new general election to the Government of Spain. In 2012 and 2013, L and G indicators decrease and the financial crisis is present. To overcome the financial crisis, a change in taxation policy is made, and taxes become an instrument of financial policy, but not an instrument of taxation policy.

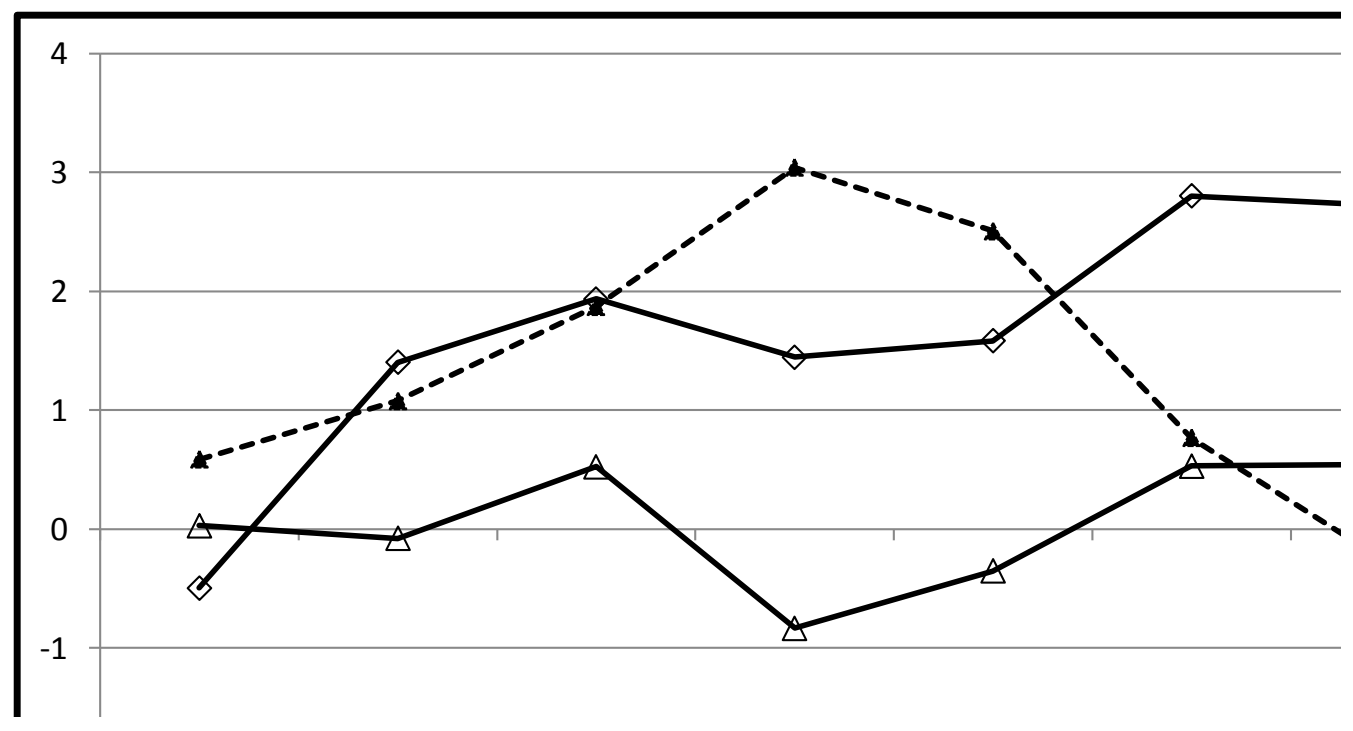

Graphic 3. Evolution of government expenses and public debt. World Bank series: Total general government expenditure (\%GDP); General government gross debt (EDP concept), consolidated annual data (\% of GDP)

\section{Discussion}

The financial crisis has put on evidence limitations on decision making based on models with internal validity. Therefore, the research has been focused at improving the quality of the explanatory variables in order to fit the internal validity of the estimation models. However, in this methodology, the removal of outliers in the Edgeworth's box means the elimination of the observations of a bank that has managed the financial crisis best and has expanded its influence through the absorption of other banks. According to this general tendency of research, the AMEB transforms accounting variables to know the behavior of economic agents and all observations in an Edgeworth's box have economic and financial significance and it allows making qualitative and quantitative analysis.

The qualitative and quantitative results attained by AMEB can find contradictions, but it is saying that there are economic disruptions on the market and the opportunism of theory of transactions costs of Williamson is present for economic agents. On the contrary, when a researcher attains a same kind of results, the opportunism has passed in markets or has been downgraded. Within these contradictions, qualitative results can guide its choice and incorporate explanatory variables in the estimation model. However, the purpose of our study aims to use the methodology for an explanatory capacity of economic events, measuring them through accounting information from banks, which act as financial agents in the economy of a country. In other words, financial statements are behavior of financial agents, which being disaffected of accounting policies can explain both the individual 
behavior of firms and the overall economy through its aggregations.

According to results obtained from Graphic 3, the excess of public debt compared to general expenses of the Spanish economy had effect on taxation policies, because public debt was applied to financial operations of government. These situation contrasts to the right positions of banks in 2010, 2011 and 2012. In this period, banks get credit from European monetary authority and, at same time, they purchased public debt. The earning of differences of interests supposed the continuity of the banking activity, but government increased taxation, following the criteria of TROIKA, (European Central Bank (ECB), International Monetary Fund (IMF) and European Commission (EC). These adjustments transformed taxes in instruments of monetary policies. So, the moral hazard is transferred to taxpayers.

In summary, one observation in the Edgeworth's box measures the activity of a company on four variables at the same time. These synthetic measures allow us to obtain qualitative and quantitative criteria on results of banking activity, which help to confirm the opinion of researchers. Moreover, all observations have economic and financial significance, including the undetermined values, because every observation will always have a limit in the Edgeworth's box

\section{Conclusion}

The accounting analysis of banking companies by the Edgeworth's box synthesizes their annual behaviors on an observation. Each observation is referred to four accounting variables, and its location in an Edgeworth's box measures the banking activity on two criteria, qualitative and quantitative. The generated zones in The Edgeworth's box allow the application of qualitative analysis, and the quantitative analysis measures the economic and financial significance of each observation in the Edgeworth's box. Comparing two kinds of results fully justifies the analysis of the banking activity. Moreover, the undetermined values that may be generated always have economic and financial significances, because accounting variables on each axes of the Edgeworth's box are positive and have a limit. This new methodology is an alternative to measure activities of banks, and is not limited by applying statistic criteria as size of samples or kind of observation of variables. Each observation has an economic and financial significance, which can be analyzed along a period, whether there is information or not in any of the years, applying either qualitative or quantitative criteria alternatively. Therefore, the Accounting science allows measuring and assessing economic and financial behaviors of companies, which can be analyzed by economic tools such as AMEB.

\section{Acknowledgements}

The author acknowledges the contribution of Miguel Pérez Raga, awarded with a C2 level of the European Framework of Languages, for the English version of this paper.

\section{References}

Allen, F., Carletti, E., Goldstein, I. \& Leonello, A. (2015). Moral Hazard and Government Guarantees in the Banking Industry. Journal of Financial Regulation, 1-21. http://finance.wharton.upenn.edu/ itayg/Files/moralhazard-published.pdf

Adrian, T., \& Shin, H. S. (2009). Money, Liquidity, and Monetary Policy. Federal Reserve Bank of New York Staff Reports, 360. http://www.newyorkfed.org/research/staff_reports/sr360.pdf.

Adams, R. B. (2012). Governance and the Financial Crisis. International Review of Finance, 12(1), 7-38. http://masters.afagh.ac.ir/cfiles/76.pdf

Aghion, P., Bacchetta, P., \& Banerjee, A. (2000). A simple model of monetary policy and currency crises. European Economic Review, 44. 728-738. http://www.hec.unil.ch/pbacchetta/Printed\%20papers/eer-00.pdf

Blandin, A., Boyd, J. H., \& Prescott, C. P. (2015). Equilibrium with Mutual Organizations in Adverse Selection Economies. Working Paper, 117. Federal Reserve Bank of Minneapolis. https://minneapolisfed.org/research/wp/wp717.pdf

Bonollo, M., Crimaldi, I., Flori, A., Pammolli, F., \&Riccaboni, M. (2015). Systemic Risk and Banking Regulation: Some Facts on the New Regulatory Framework. IMT. Lucca Eic, Working Paper Series 01/2015. http://eprints.imtlucca.it/2455/.

Caporale, C., Rault, Ch., Sova, A. D., \& Sova, R. (2015). Financial Development and Economic Growth: Evidence from 10 New European Union Members. International Journal of Finance \& Economics, 20, 48-60. http://onlinelibrary.wiley.com/doi/10.1002/ijfe.1498/full

Chistiano, A.B., Gust, Ch., \& Roldosd, J. (2004). Monetary policy in a financial crisis, Journal of Economic Theory, 119. $64-103$ 
Gertler, M., Gilchrist, S., \& Natalucci, F. M. (2007). External Constraints on Monetary Policy and the Financial Accelerator. Journal of Money, Credit and Banking, 39(2-3), 295-330.

IOSCO. (2009). General Principles Regarding Disclosure of Management's Discussion and Analysis of Financial Condition and Results of Operations. Report of the Technical Committee of the International Organization of Securities Commissions. https://www.iosco.org/library/pubdocs/pdf/IOSCOPD141.pdf

IASB (2010). Management Commentary. IFRS Practice Statement: A framework for presentation. http://www.ifrs.org/Current-Projects/IASB-Projects/Management-Commentary/IFRS-Practice-Statement/Pages/IF RS-Practice-Statement.aspx

Moritz Schularick, M., \& Taylor, A. M. (2009). Credit Booms Gone Bust: Monetary Policy, Leverage Cycles and Financial Crises, 1870-2008. National Bureau of Economic Research. Working Paper, 15512. http://www.nber.org/papers/w15512.

Pérez Benedito, M. A. (2014). Accounting Analysis of Economic Policy of Spain (2012). Theoretical Economics Letters. 3, 254-261. http://www.scirp.org/journal/PaperInformation.aspx?PaperID=45292.

Pérez Benedito, M. A. (2015). The Accounting Analysis of Banking Company: The Case of CAM. Modern Economy. 179-189. http://www.scirp.org/journal/PaperInformation.aspx?paperID=53829

Taylor, J. B. (2009). The Financial Crisis and the Policy Responses: an Empirical Analysis of What Went Wrong. National Bureau of Economic Research. Working Paper 14631. http://www.nber.org/papers/w14631.

Suh, S. (2015), Measuring sovereign risk contagion in the Eurozone. International Review of Economics and Finance, $35,45-65$.

Appendix A

Banking companies of IBEX35

\begin{tabular}{|c|c|c|c|c|c|c|c|c|c|}
\hline SANTANDER & 2013 & 2012 & 2011 & 2010 & 2009 & 2008 & 2007 & 2006 & 2005 \\
\hline IND. L & 0,588 & $-1,778$ & $-0,916$ & $-0,670$ & 1,376 & 0,910 & 0,476 & 0,695 & $-0,089$ \\
\hline IND. G & $-1,530$ & 0,243 & $-0,099$ & 0,509 & $-0,325$ & $-0,279$ & 0,462 & $-0,110$ & 0,100 \\
\hline B BVA & 2013 & 2012 & 2011 & 2010 & 2009 & 2008 & 2007 & 2006 & 2005 \\
\hline IND. L & $-1,3439$ & 0,2232 & $-0,1915$ & $-1,1555$ & 0,1789 & 0,5112 & 0,9609 & 0,3016 & $-0,1559$ \\
\hline IND. G & $-0,4100$ & 0,0680 & 0,1440 & $-0,1492$ & $-0,0893$ & $-0,5814$ & 0,2034 & 0,0060 & $-0,0270$ \\
\hline CAIXA B & 2013 & 2012 & 2011 & 2010 & 0 & 0 & 0 & 0 & 0 \\
\hline IND. L & 0,3129 & 0,4798 & $-1,4989$ & 2,9080 & 0 & 0 & 0 & 0 & 0 \\
\hline IND. G & $-0,0295$ & 0,3414 & $-0,1341$ & 0,2080 & 0 & 0 & 0 & 0 & 0 \\
\hline B SBDELL & 2013 & 2012 & 2011 & 2010 & 2009 & 2008 & 2007 & 2006 & 2005 \\
\hline IND. L & 3,299 & 3,362 & $-1,044$ & 1,335 & 0,687 & 0,755 & 1,766 & 1,420 & $-1,597$ \\
\hline IND. G & 0,445 & 1,498 & 0,105 & $-0,206$ & $-0,158$ & 0,063 & $-0,622$ & 0,307 & 0,147 \\
\hline POPULAR & 2013 & 2012 & 2011 & 2010 & 2009 & 2008 & 2007 & 2006 & 2005 \\
\hline IND. L & 0,3871 & 0,5517 & $-1,3377$ & $-1,0721$ & 0,8705 & $-0,0238$ & 1,2172 & 0,5274 & $-0,0384$ \\
\hline IND. G & 0,0456 & 0,4927 & $-0,1530$ & $-0,6428$ & 0,0854 & $-0,0043$ & $-0,0131$ & $-0,0512$ & $-0,1662$ \\
\hline BANKINTER & 2013 & 2012 & 2011 & 2010 & 2009 & 2008 & 2007 & 2006 & 2005 \\
\hline IND. L & $-0,4817$ & 1,7658 & 0,9386 & $-1,2965$ & $-1,2503$ & 0,1229 & 1,4082 & 0,9172 & $-0,1711$ \\
\hline IND. G & $-0,1537$ & $-0,0173$ & $-0,0274$ & $-0,3017$ & 0,1245 & $-0,2542$ & $-0,0179$ & 0,0034 & 0,0001 \\
\hline B RENTA 4 & 2013 & 2012 & 2011 & 0 & 0 & 0 & 0 & 0 & 0 \\
\hline IND. L & $-1,5050$ & 0,2661 & 0,4959 & 0 & 0 & 0 & 0 & 0 & 0 \\
\hline IND. G & $-0,0242$ & $-0,0047$ & 0,0702 & 0 & 0 & 0 & 0 & 0 & 0 \\
\hline BANKIA & 2013 & 2012 & 2011 & 2010 & 0 & 0 & 0 & 0 & 0 \\
\hline IND. L & $-0,0392$ & $-1,2540$ & $-0,2533$ & 3,6780 & 0 & 0 & 0 & 0 & 0 \\
\hline IND. G & $-0,0195$ & 0,3269 & 0,0151 & 0,4732 & 0 & 0 & 0 & 0 & 0 \\
\hline
\end{tabular}




\begin{tabular}{lcccccc}
\hline CAH MED & 2010 & 2009 & 2008 & 2007 & 2006 & 2005 \\
IND. L & 0,538 & $-1,624$ & $-0,442$ & 1,613 & 1,375 & $-0,412$ \\
IND. G & $-0,007$ & 0,508 & $-0,024$ & $-0,125$ & 0,016 & $-0,302$ \\
\hline
\end{tabular}

\section{Appendix B}

Prove of t-Student between monetary variables and indicators of AMEB

\begin{tabular}{lrrrrrr}
\hline \multicolumn{1}{c}{ Statistics } & IND. $L$ & SI_l_3.46 & IND. L & SI_1_3.28 & IND. G & SI_1_3.46 \\
\hline Mean & 1,5149 & 85,6889 & 1,5149 & $-4,3556$ & $-0,1419$ & 85,6889 \\
Variance & 1,0689 & 13,8236 & 1,0689 & 267,9053 & 0,8418 & 13,8236 \\
Observations & 9 & 9 & 9 & 9 & 9 & 9 \\
Pearson & 0,9061 & & $-0,7135$ & & 0,4902 & \\
Hypothesis Diferences means & 0 & 0 & & 0 & \\
Degrees of Freedom & 8 & 8 & & $-76,5285$ & \\
Statistic t & $-89,6918$ & & 1,0287 & & 0,0000 & \\
P(T<=t) one-tailed & 0,0000 & 0,1669 & & 1,8595 & \\
Critical Value t (one tail) & 1,8595 & & 1,8595 & & 0,0000 & \\
P(T<=t) two-tailed & 0,0000 & & 0,3337 & & 2,3060 & \\
Critical value t (two tails) & 2,3060 & & 2,3060 & & & \\
\hline
\end{tabular}

Series of Spanish Bank:

\begin{tabular}{|c|c|c|c|c|}
\hline Statistics & IND. $G$ & SI_1_3.28 & IND. L & IND. G \\
\hline Mean & $-0,1419$ & $-4,3556$ & 1,5149 & $-0,1419$ \\
\hline Variance & 0,8418 & 267,9053 & 1,0689 & 0,8418 \\
\hline Observations & 9 & 9 & 9 & 9 \\
\hline Pearson & $-0,6720$ & & 0,5324 & \\
\hline Hypothesis Diferences means & 0 & & 0 & \\
\hline Degrees of Freedom & 8 & & 8 & \\
\hline Statistic t & 0,7437 & & 5,2376 & \\
\hline $\mathrm{P}(\mathrm{T}<=\mathrm{t})$ one-tailed & 0,2392 & & 0,0004 & \\
\hline Critical Value t (one tail) & 1,8595 & & 1,8595 & \\
\hline $\mathrm{P}(\mathrm{T}<=\mathrm{t})$ two-tailed & 0,4783 & & 0,0008 & \\
\hline Critical value t (two tails) & 2,3060 & & 2,3060 & \\
\hline
\end{tabular}

SI_1_3.46 = Quarterly Financial Accounts. Household debt and Nonprofit institutions. Percentage of GDP// Cuentas financieras trimestrales. Endeudamiento de los hogares e ISFL. Porcentaje sobre el PIB (Spanish)

SI_1_3.28 = National financial figures. Financial assets of non-financial corporations and households and NPI. Investment funds bond in euros. Rate interannual variation//Magnitudes financieras nacionales. Activos financieros de Sociedades no financieras y hogares e ISFL. Fondos de inversión de renta fija en euros. Tasa de variación interanual (Spanish)

\section{(c) EY}

This work is licensed under a Creative Commons Attribution 3.0 License. 